\title{
Study on the Mechanical Relationship among the Backfilling Mining Support, Roof Rock Beam, and Gangue Filling Body in Comprehensive Mechanized Filling Mining Process
}

\author{
Zhimin Huang $\mathbb{D}^{1}{ }^{1}$ Lei Zhang $\mathbb{D}^{1}{ }^{1}$ and Zhanguo $\mathrm{Ma}^{2}$ \\ ${ }^{1}$ School of Materials Science and Physics, China University of Mining e Technology, Xuzhou, Jiangsu 221116, China \\ ${ }^{2}$ State Key Laboratory for Geomechanics and Deep Underground Engineering, School of Mechanics and Civil Engineering, \\ China University of Mining \& Technology, Xuzhou, Jiangsu 221116, China
}

Correspondence should be addressed to Lei Zhang; cumtzl@126.com

Received 25 June 2020; Revised 20 September 2020; Accepted 3 October 2020; Published 27 October 2020

Academic Editor: Hailing Kong

Copyright $(2020$ Zhimin Huang et al. This is an open access article distributed under the Creative Commons Attribution License, which permits unrestricted use, distribution, and reproduction in any medium, provided the original work is properly cited.

Based on the theory of elastic foundation beam, the mechanical model of the backfilling mining support-roof rock beam-gangue filling body under the condition of comprehensive mechanized filling mining is established. The foundation coefficient of each part is determined, and the subsidence of each part of roof rock beam is calculated. It is found that the initial filling height is the decisive factor to control the subsidence and migration stability of each part of the roof rock beam. Properly increasing the pushing force of backfilling-coal mining hydraulic support on the filling body can also effectively control the roof subsidence. The comprehensive mechanized filling mining process was studied by similar simulation experiments, it is found that the influence law of initial filling height on roof rock beam subsidence is the same as that of theoretical analysis, and the experimental measurement values and fitting function relationships are consistent with the theoretical calculation results.

\section{Introduction}

In recent years, under the guidance of the concepts of "green mining" and "scientific mining" $[1,2]$, the scientific mining of coal has made rapid development [3-8]. The comprehensive mechanized solid filling mining technology solves the organic combination problem of "three down" mining technology and comprehensive mining technology and realizes the production mode of high mining rate, high yield, high efficiency, and low cost under buildings $[9,10]$. A large number of engineering practices put forward higher and higher requirements for basic research on strata control theory and mechanical properties of filling body under the condition of filling mining. Many scholars have carried out a lot of theoretical and experimental studies in this regard [11-22]. In the process of filling coal mining, after the filling body is tamped by the hydraulic support of filling coal mining, it will replace the raw coal to support the overlying strata, so that the movement and fracture of the overlying strata are significantly reduced. Therefore, on one hand, no caving zone will be formed, and on the other hand, the height of the fracture zone will be greatly decreased, and there may even be no fracture zone. The goaf is filled with gangue. The filling body is in the form of scattered fragments and granular structure, and its movement process is in the form of consolidation and compaction. Most of the strata above are curved subsidence zones, the rock mass structure is relatively complete, and the strata are cut regularly by the layers, so that the structure body presents a layered structure of normal heterogeneity and tangential homogeneity. The deformation form of rock mass structure is the bending deformation of beam or slab [23]. Under the condition of filling mining, the filling body has a strong control effect on the overlying strata, and the roof subsidence and internal force are greatly reduced; therefore, in theory, the basic roof or key layer is generally regarded as the beam or plate on the elastic foundation to consider the interaction between the roof, support, and filling body. The foundation coefficient of the filling body reflects the supporting role of the filling body, and its value is directly related to the compaction 
mechanical characteristics of the gangue filling body. Therefore, on the basis of fully understanding the mechanical properties of the gangue filling body, a more accurate mechanical model of "backfilling mining supportroof rock beam-filling body" need to be established, which has important theoretical value and practical significance for improving the theoretical system of the relationship between strata movement and support surrounding rock in solid filling coal mining.

Based on the elastic foundation beam theory, this paper establishes the mechanical model of the backfilling mining support-roof rock beam-gangue filling body. The influence of initial filling height and compaction force of filling support on the subsidence of roof rock beam is studied by solving the differential equation of the subsidence of roof rock beam under the condition of comprehensive mechanized filling mining, and the results are verified by similar simulation experiments.

\section{Mechanical Model of "Backfilling Mining Support-Roof Rock Beam-Filling Body" and the Analysis}

2.1. Mechanical Model. Under the condition of comprehensive mechanized mining and dense filling, rock beam, coal body and filling body can be regarded as elastic foundation, and the mechanical model of elastic foundation beam of roof rock beam is established. The relationship among backfilling mining support, roof rock beam, and filling body is shown in Figure 1(a), and the mechanical model is shown in Figure 1(b).

In Figure 1, the roof can be regarded as an infinitely long elastic foundation beam of unit width, with thickness of $h$. The weight of the overlying strata produces a distributed load of concentration $q$ on the beam. The leading force of the front coal seam on the roof is $p_{1}(x)$, and the thickness of the coal seam is $H_{0}$. The overlying strata is supported by the backfilling mining support within the top control area, with force $p_{2}(x)$ and length of $l$, and the mined area outside the top control area of the mining face is supported by the gangue filling body, with force $p_{3}(x)$.

The coordinate origin $\mathrm{O}$ is selected at the coal wall. The positive direction of the $x$-axis is to the right, and the positive direction of the $y$-axis is downward. This paper discusses the near horizontal coal seam, and horizontal left is the advancing direction of mining face. The horizontal position $x$ is taken as the independent variable and the displacement function $y(x)$ is taken as the basic unknown quantity. Under the action of load $q$, the subsidence of roof rockbeam at the coal wall is $h_{0}$. On the side of goaf, the subsidence of roof rock beam at the position of maximum roof distance control is $h_{0}+h_{1}$, and $h_{1}$ is the subsidence before the roof rock beam touches the gangue filling body.

Based on the Winkler foundation assumption, the subsidence equation of roof rock beam under the condition of comprehensive mechanized filling mining can be listed as

$$
\begin{aligned}
& E I \frac{0^{4} y}{0 x^{4}}=q+\gamma h-p_{1}, \quad x<0, \\
& E I \frac{0^{4} y}{0 x^{4}}=q+\gamma h-p_{2}, \quad 0 \leq x \leq l, \\
& E I \frac{0^{4} y}{0 x^{4}}=q+\gamma h-p_{3}, \quad x>l .
\end{aligned}
$$

Among them, the coal body and filling body are simplified as the elastic foundation, meeting Winkler foundation assumption:

$$
\begin{aligned}
& p_{1}=k_{1} y \quad(x<0), \\
& p_{3}=k_{3}\left(y-h_{0}-h_{1}\right) \quad(x>l) .
\end{aligned}
$$

For the support force $p_{2}$, according to the working conditions of the comprehensive mechanized filling mining, considering that the active support function of the filling hydraulic support is mainly to make the rear roof beam of the support resist the bending and sinking of the roof, the active load of the support is assumed to be:

$$
p_{2}=p_{a}+\frac{p_{b}-p_{a}}{l} x, \quad 0 \leq x \leq l .
$$

In equations (1)-(3), $E$ and $I$ are the elastic modulus and section inertia moment of the roof rock beam respectively, and $\gamma$ is the bulk density of the rock beam, $k_{1}$ is the foundation coefficient of the coal seam and $k_{3}$ is the foundation coefficient of filling gangue. $p_{a}$ and $p_{b}$ are the support loads at the front and back of the support, respectively.

Equation (1) is solved firstly. For the form of the homogeneous equation corresponding to equation (1), let

$$
\alpha_{1}=\frac{\sqrt{2}}{2} \sqrt[4]{\frac{k_{1}}{E I}} .
$$

The general solution is

$$
\begin{aligned}
y_{0}= & e^{\alpha_{1} x}\left(A_{1} \sin \alpha_{1} x+A_{2} \cos \alpha_{1} x\right) \\
& +e^{-\alpha_{1} x}\left(A_{3} \sin \alpha_{1} x+A_{4} \cos \alpha_{1} x\right) .
\end{aligned}
$$

The special solution is $y^{*}=(q+\gamma h) / k_{1}$; therefore, the solution of equation (1) can be expressed as: $y=y_{0}+y^{*}$.

Because the rock beam is not affected by mining at the far end of both sides, there are $y=(q+\gamma h) / k_{1}$ when $x=-\infty$.

By substituting the general solution, we can get $A_{3}=A_{4}=0$.

Therefore, the solution of equation (1) is

$$
y_{1}=e^{\alpha_{1} x}\left(A_{1} \sin \alpha_{1} x+A_{2} \cos \alpha_{1} x\right)+\frac{q+\gamma h}{k_{1}}, \quad x<0 .
$$

Using the same method, let $\alpha_{2}=(\sqrt{2} / 2) \sqrt[4]{k_{3} / E I}$, the solution of equation (3) can be obtained as follows:

$$
y_{3}=e^{-\alpha_{2} x}\left(C_{3} \sin \alpha_{2} x+C_{4} \cos \alpha_{2} x\right)+\frac{q+\gamma h}{k_{3}}+h_{0}+h_{1}, \quad x>l .
$$




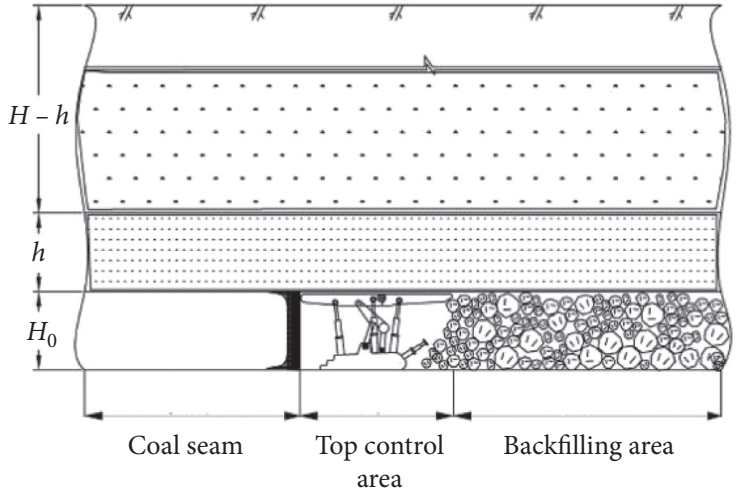

(a)

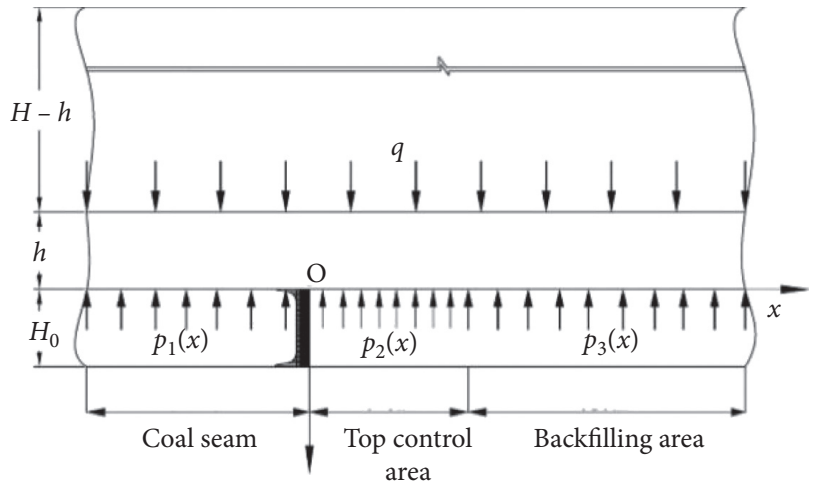

(b)

FIGURE 1: Mechanical model of backfilling mining support-roof rock beam-filling body.

Finally, equation (2) is solved through integration directly, the solution is

$$
\begin{aligned}
y_{2}= & \frac{p_{a}-p_{b}}{120 E I l} x^{5}+\frac{q+\gamma h-p_{a}}{24 E I} x^{4}+B_{1} x^{3}+B_{2} x^{2} \\
& +B_{3} x+B_{4}, \quad 0 \leq x \leq l .
\end{aligned}
$$

The coefficients $A_{1}, A_{2}, B_{1}, B_{2}, B_{3}, B_{4}, C_{3}$, and $C_{4}$ in equations (8)-(10) can be obtained by using the boundary continuity conditions of the boundary between the support and the coal wall $(x=0)$ and the boundary between the support and the filling body $(x=l)$ :

$$
\begin{aligned}
& x=0:\left\{\begin{array}{l}
y_{1}=y_{2}, \\
y_{1}^{\prime}=y_{2}^{\prime}, \\
y_{1}^{\prime \prime}=y_{2}^{\prime \prime}, \\
y_{1}^{\prime \prime \prime}=y_{2}^{\prime \prime \prime},
\end{array}\right. \\
& x=l:\left\{\begin{array}{l}
y_{2}=y_{3}, \\
y_{2}^{\prime}=y_{3}^{\prime}, \\
y_{2}^{\prime \prime}=y_{3}^{\prime \prime}, \\
y_{2}^{\prime \prime \prime}=y_{3}^{\prime \prime \prime} .
\end{array}\right.
\end{aligned}
$$

As the foundation coefficient $k$ in Winkler foundation model is related to the deformation modulus $E_{\mathrm{s}}$ and the thickness $H$ of the foundation, when both sides of the compression layer are free of deformation,

$$
k=\frac{E_{\mathrm{s}}}{H}
$$

In the questions studied above, for $k_{1}, H$ is the mining height $H_{0}$, while for $k_{3}, H$ is the height of the filling body foundation $\mathrm{H}_{3}$, which is affected by the allowable pressure height of the support during the filling mining process and the initial filling rate. $\mathrm{H}_{3}$ can be expressed as

$$
H_{3}=H_{0}-h_{0}-h_{1} \text {. }
$$

Similarly, for $k_{1}, E_{\mathrm{s}}$ is the deformation modulus of the solid coal foundation $E_{\mathrm{s} 0}$; while for $k_{3}, E_{\mathrm{s}}$ corresponds to the deformation modulus of the filling body foundation $E_{\mathrm{s} 3}$. $E_{\mathrm{s} 3}$ is mainly affected by the compaction force of the support on the filling body during the filling mining process. According to the compaction mechanical property test of the slag mixture filling body [24], it can be seen that there is a linear relationship between $E_{\mathrm{s} 3}$ and the compaction stress $\sigma$, and can be expressed as

$$
E_{\mathrm{s} 3}=a_{4}+b_{4} \sigma .
$$

Therefore, $k_{1}$ and $k_{3}$ can be expressed as

$$
\begin{aligned}
& k_{1}=\frac{E_{\mathrm{s} 0}}{H_{0}}, \\
& k_{3}=\frac{E_{\mathrm{s} 3}}{H_{3}}=\frac{a_{4}+b_{4} \sigma}{H_{0}-h_{0}-h_{1}},
\end{aligned}
$$

where $\mathrm{H}_{3}$ is the thickness of the foundation, which is equal to the initial filling height $h_{\mathrm{g}}$ of the filling area, so $k_{3}$ can also be expressed as

$$
k_{3}=\frac{E_{\mathrm{s} 3}}{h_{\mathrm{g}}}=\frac{a_{4}+b_{4} \sigma}{h_{\mathrm{g}}} .
$$

It can be seen that for a given gangue filling material, the value of $k_{3}$ is affected by two factors, the initial filling height $h_{\mathrm{g}}$ and the compaction stress $\sigma$ that the filling body bears. Substituting equation (16) into (8)-(10) can get the relationship among the amount of roof rock beam subsidence and $h_{\mathrm{g}}, \sigma, H_{0}, E, I, k_{1}$, etc.

Taking a coal mine in Shanxi Province, China, as an example for analysis, take $h=4 \mathrm{~m}, H_{0}=3 \mathrm{~m}, E=10 \mathrm{GN} / \mathrm{m}^{2}$, $I=5.33, \quad q=3.11 \mathrm{MPa}, \quad \gamma=25 \mathrm{kN} / \mathrm{m}^{3}, \quad p_{a}=0.73 \mathrm{MPa}$, $p_{b}=0.80 \mathrm{MPa}, l=7.5 \mathrm{~m}$, and $k_{1}=0.6 \mathrm{GN} / \mathrm{m}^{2}$. According to equation (14), the fitting coefficient of primary slag mixture $\left(a_{4}=-433702, b_{4}=15.987\right)$ is selected, then equation (17) can be obtained:

$$
E_{\mathrm{s}}=-433702+15.987 \sigma .
$$

The relationship among $y_{1}, y_{2}, y_{3}$, and $h_{\mathrm{g}}$ and $\sigma$ will be discussed below. Substituting the above parameters into equations (8) to (10), the expressions for $y_{1}, y_{2}$, and $y_{3}$ can be obtained as follows: 


$$
\begin{gathered}
y_{1}=0.00535+e^{0.23 x}\left[A_{2} \cos (0.23 x)+A_{1} \sin (0.23 x)\right] \\
y_{2}=B_{4}+B_{3} x+B_{2} x^{2}+B_{1} x^{3}+1.939 \times 10^{-6} x^{4}-1.459 \times 10^{-9} x^{5} \\
y_{3}=3-h_{\mathrm{g}}+\frac{3.21 \times 10^{6} h_{\mathrm{g}}}{-433702+15.987 \sigma}+e^{-2.081 \times 10^{-3} x\left((-433702+15.987 \sigma) / h_{\mathrm{g}}\right)^{1 / 4}} \\
\left\{C_{4} \cos \left[2.081 \times 10^{-3} x\left(\frac{-433702+15.987 \sigma}{h_{\mathrm{g}}}\right)^{1 / 4}\right]+C_{3} \sin \left[2.081 \times 10^{-3} x\left(\frac{-433702+15.987 \sigma}{h_{\mathrm{g}}}\right)^{1 / 4}\right]\right\}
\end{gathered}
$$

In the equation, the coefficients $A_{1}, A_{2}, B_{1}, B_{2}, B_{3}, B_{4}, C_{3}$, and $C_{4}$ are all related to $\sigma$ and $h_{\mathrm{g}}$. For each set of $\sigma$ and $h_{\mathrm{g}}$ values, the specific expressions of $y_{1}, y_{2}$, and $y_{3}$ can be obtained. The effects of $\sigma$ and $h_{\mathrm{g}}$ on $y_{1}, y_{2}$, and $y_{3}$ will be discussed below, respectively.

\subsection{Effect of Initial Filling Height on Roof Rock Beam} Subsidence. The roof's subsidence amount $\left.y_{1}\right|_{x=0}$ at the coal wall $x=0$, the roof s subsidence amount $y_{2}$ above the support and the roof s subsidence amount $y_{3}$ above the gangue filling body are calculated in the condition of the compaction stress $\sigma=2 \mathrm{MPa}$ and $h_{\mathrm{g}}=1.8 \mathrm{~m}, 2.1 \mathrm{~m}, 2.4 \mathrm{~m}, 2.7 \mathrm{~m}$ and $2.85 \mathrm{~m}$ respectively, which are substituted into equations (18)-(20). The results are shown in Figure 2.

It can be seen from the figure that when the filling body is subjected to the pushing and pressing stress of $2 \mathrm{MPa}$ of the support tamping mechanism, different positions of the roof rock beams sink in different degrees after filling. For dense filling mining, under the pushing and pressing action of tamping mechanism, the filling body can be connected to the top basically. However, due to mining, a certain subsidence occurs before the roof hits the gangue, so the initial filling height $h_{\mathrm{g}}$ is also different. The magnitude of $h_{\mathrm{g}}$ has a significant effect on the subsidence of the roof rock beam.

First of all, the larger $h_{\mathrm{g}}$ is, the smaller the final stable subsidence of the roof rock beam above the filling area is. When $h_{\mathrm{g}}=1.8 \mathrm{~m}$, the filling height is $60 \%$ of the mining height, and the final stable subsidence of the roof above the filling area is $1.38 \mathrm{~m}$; when $h_{\mathrm{g}}=2.4 \mathrm{~m}$, the filling height is $80 \%$ of the mining height, and the final stable subsidence of the roof above the filling area is $0.85 \mathrm{~m}$; when $h_{\mathrm{g}}=2.85 \mathrm{~m}$, the filling height is $95 \%$ of the mining height, and the final stable subsidence of the roof above the filling area is only $0.44 \mathrm{~m}$.

Secondly, subsidence $y_{3}$ of the rock beam above the filling body increases with the increase of the distance $x$ from the coal wall. After a certain distance is filled, the subsidence of the rock beam above the filling body can reach stability, so $h_{\mathrm{g}}$ has a great influence on the distance of the final stable subsidence of the roof rock beam. When $h_{\mathrm{g}}=2.85 \mathrm{~m}$, $x=25 \mathrm{~m}$ (filling distance behind the support is about $17 \mathrm{~m}$ ), $y_{3}$ tends to be stable; when $h_{\mathrm{g}}=2.4 \mathrm{~m}, x=30 \mathrm{~m}$ (filling distance behind the support is about $22 \mathrm{~m}$ ), $y_{3}$ tends to be stable; when $h_{\mathrm{g}}=1.8 \mathrm{~m}, x=40 \mathrm{~m}$ (filling behind the support is about $32 \mathrm{~m}$ ), $y_{3}$ tends to be stable.

Thirdly, no matter what the height of $h_{\mathrm{g}}$ is equal to, the subsidence $y_{2}$ of the rock beam above the support increases with the increase of $x$, and basically satisfies the linear relationship. The subsidence at the front end of the support is small, and the subsidence at the back end of the support is large. At the same time, the subsidence of the roof above the support decreases with the increase of $h_{\mathrm{g}}$.

Finally, the subsidence $\left.y_{1}\right|_{x=0}$ of coal wall decreases with the increase of $h_{\mathrm{g}}$, and basically satisfies the linear relationship. The filling height increases from $60 \%$ to $95 \%$ of the mining height, which can reduce the subsidence of the coal wall from $0.199 \mathrm{~m}$ to $0.067 \mathrm{~m}$, a decrease of nearly $2 / 3$. It can be seen that increasing the initial filling height can effectively control the subsidence and migration stability of each part of roof rock beam.

2.3. The Influence of Compaction Force of Self-Ramming Backfill Mining Hydraulic Support on the Subsidence of Roof Rock Beam. When $h=4 \mathrm{~m}, H_{0}=3 \mathrm{~m}, E=10 \mathrm{GN} / \mathrm{m}^{2}, I=5.33$, $q=3.11 \mathrm{MPa}, \gamma=25 \mathrm{kN} / \mathrm{m}^{3}, p_{a}=0.73 \mathrm{MPa}, p_{b}=0.80 \mathrm{MPa}$, $l=7.5 \mathrm{~m}, \quad k_{1}=0.6 \mathrm{GN} / \mathrm{m}^{2}, \quad a_{4}=-433702, \quad b_{4}=15.987$, $h_{\mathrm{g}}=2.4 \mathrm{~m}$, and $\sigma$ is taken as $1.0 \mathrm{MPa}, 1.5 \mathrm{MPa}, 2.0 \mathrm{MPa}$, $2.5 \mathrm{MPa}, 3.0 \mathrm{MPa}$ respectively, $y_{1 \mid x=0}, y_{2}, y_{3}$ are calculated during equations (17) (20). The influence of filling push pressure stress on the subsidence of roof rock beam is discussed, as shown in Figure 3.

It can be seen from the figure that when the self-ramming backfill mining hydraulic support exerts different amounts of compaction force on the filling body, the amount of subsidence of the roof rock beam will also change in different sizes.

First of all, $\sigma$ has a great influence on the final stable subsidence of the roof rock beam in the filling area. The larger $\sigma$ is, the smaller the final subsidence is. It can also be seen that when $\sigma$ increases from 1.0 MPa to 2.0 MPa, the final subsidence of $y_{3}$ decreases by $0.25 \mathrm{~m}$; when $\sigma$ increases to $3.0 \mathrm{MPa}$, the final subsidence of $y_{3}$ only decreases by $0.09 \mathrm{~m}$. Therefore, when the compaction stress is about 2.0 MPa, the subsidence of the roof rock beam can be effectively controlled. If the compaction stress is increased more on this basis, this control effect will not increase significantly.

Secondly, $\sigma$ also has a certain influence on the distance of the final stable subsidence of the roof beam above the filling area. When $\sigma=3.0 \mathrm{MPa}, x=25 \mathrm{~m}$ (filling distance behind the support is about $17 \mathrm{~m}), y_{3}$ tends to be stable; when $\sigma=1.0 \mathrm{MPa}, x=45 \mathrm{~m}$ (filling distance behind the support is about $37 \mathrm{~m}$ ). $y_{3}$ tends to be stable. It can be observed that the smaller the compaction stress is, the longer the unstable area of roof subsidence movement is. 


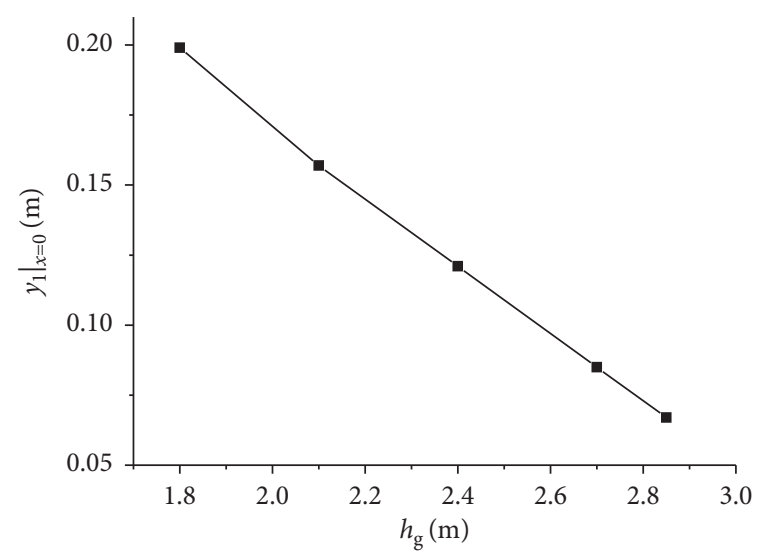

(a)

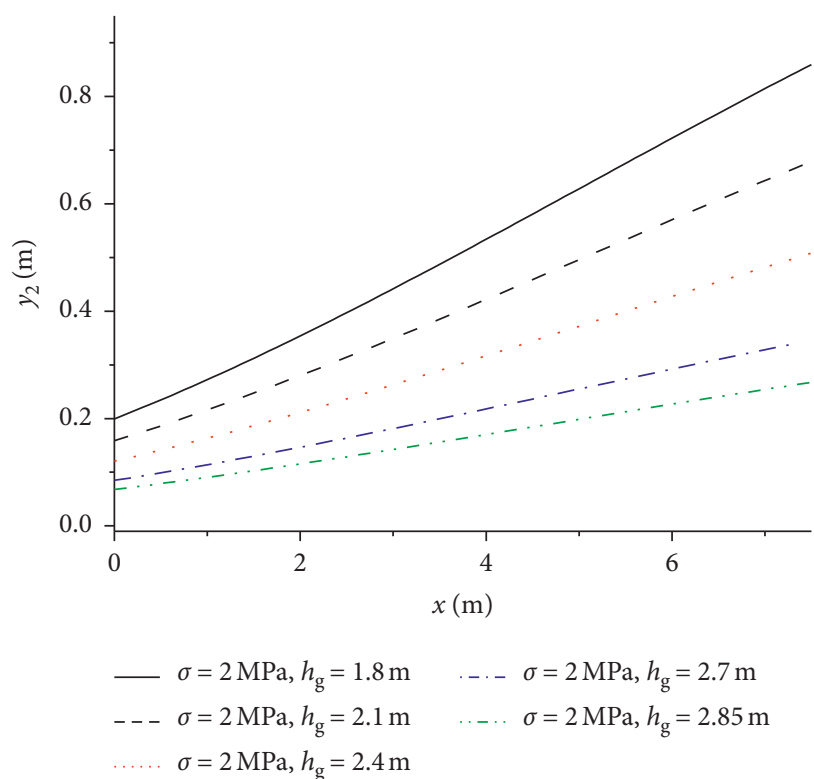

(b)

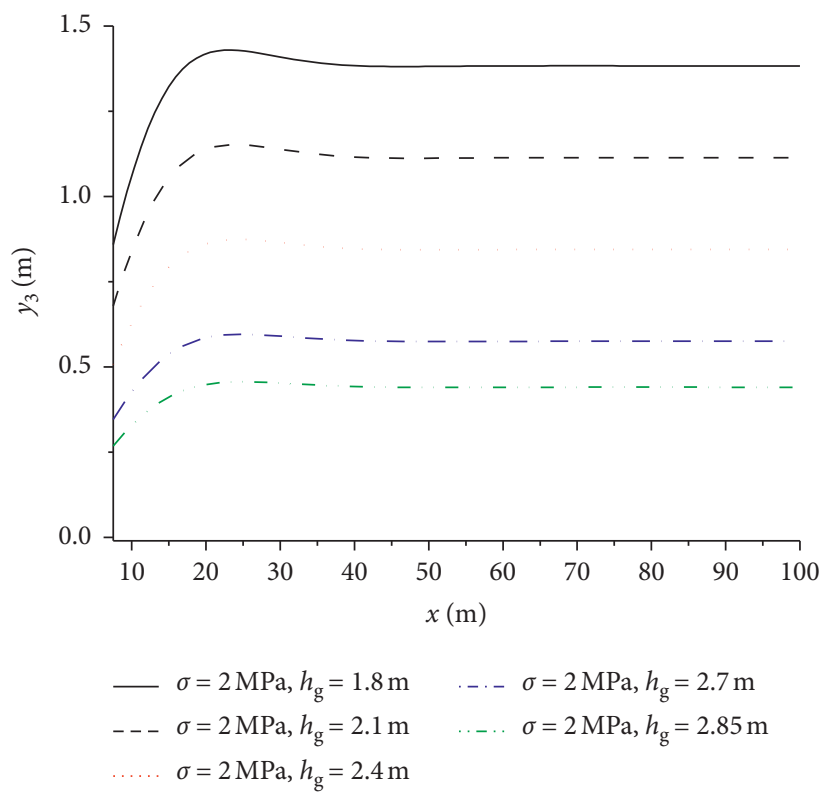

(c)

Figure 2: Roof's subsidence amount with different $h_{\mathrm{g}}$. (a) Roof's subsidence amount of coal wall. (b) Roof's subsidence amount above the support. (c) Roof's subsidence amount above the gangue filling body.

Thirdly, when the compaction stress $\sigma$ changes, the subsidence $y_{2}$ of the rock beam above the support still increases with the increase of $x$, and basically satisfies the linear relationship. The subsidence at the front end of the bracket is small, and the subsidence at the back end of the bracket is large. At the same time, the subsidence of the roof decreases with the increase of $\sigma$.

Finally, the subsidence $\left.y_{1}\right|_{x=0}$ of coal wall decreases with the increase of $\sigma$, but it is nonlinear. In general, $\sigma$ has little effect on the subsidence of coal wall. It can be seen that increasing the compaction stress $\sigma$ of the support can effectively compact the back part of the backfilling body and increase its deformation modulus, thus controlling the subsidence and instability range of the roof rock beam.

\section{Physical Simulation of Comprehensive Mechanized Filling Mining}

Similar material simulation experiment is not only intuitive and repeatable, but also an experimental method with good condition control flexibility and high efficiency. Therefore, it has become an important means to study the characteristics of strata movement and the law of mine pressure change in mining engineering. In this paper, on the basis of the 


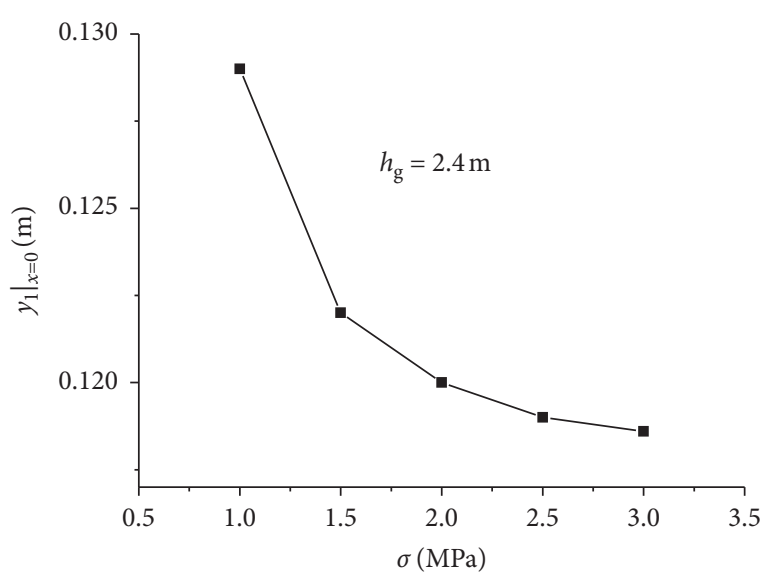

(a)

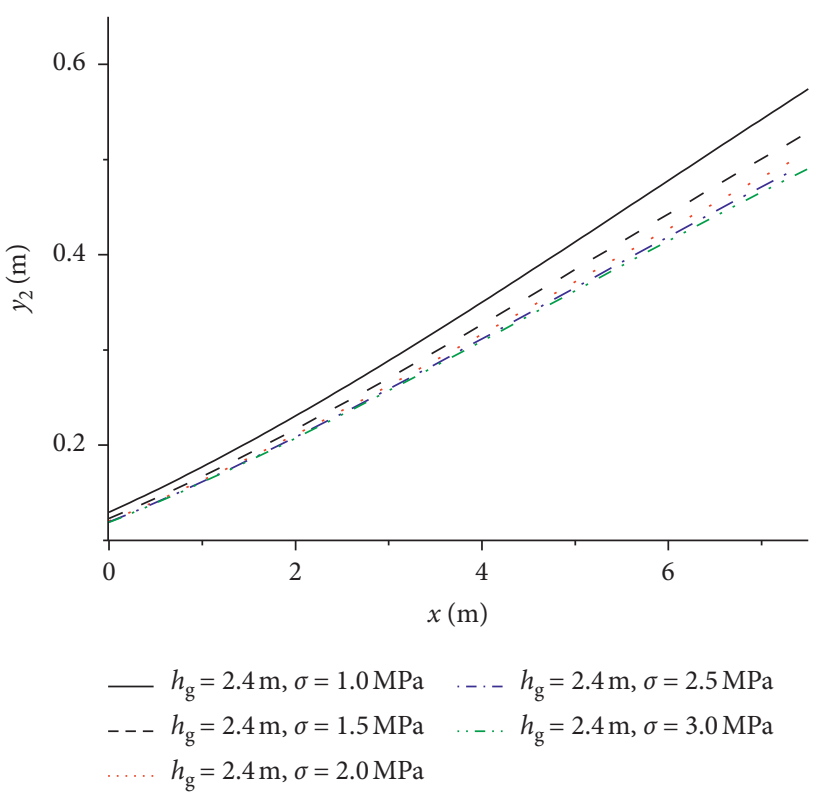

(b)

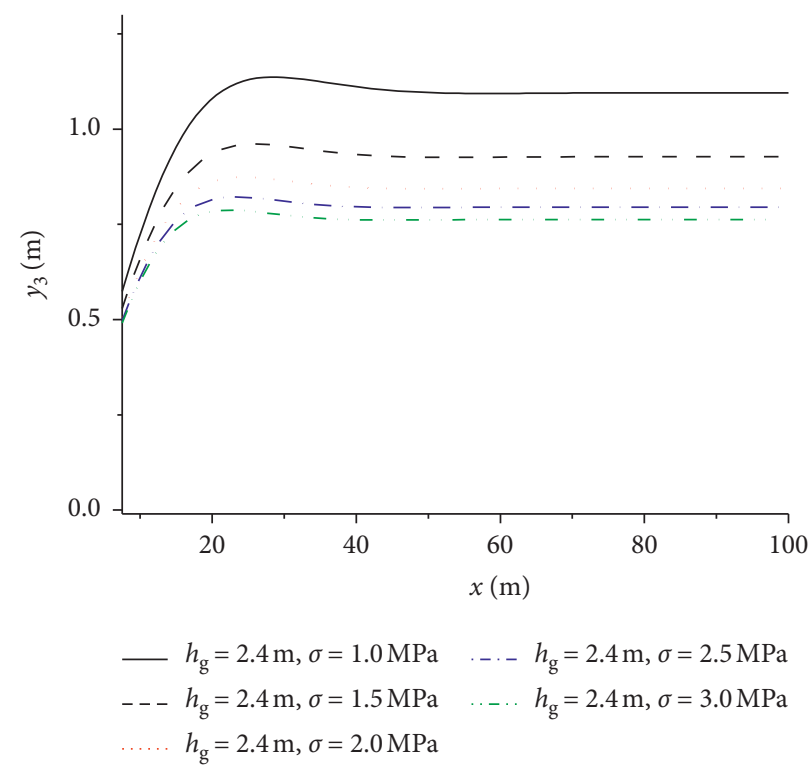

(c)

Figure 3: Roof's subsidence with different $\sigma$. (a) Roof's subsidence of coal wall. (b) Roof's subsidence above the support. (c) Roof's subsidence above the gangue filling body.

theoretical study of the mechanical model of filling mining, with the help of similarity theory, the simulation experiment of similar materials is carried out to observe the movement, failure, and stress change of rock strata in the process of filling mining and verify the theoretical calculation results.

3.1. Equipments and Materials of Similar Material Model Experiment. In a similar material model experiment, the plane model test bench with the length $\times$ height $\times$ width $=2.50 \mathrm{~m} \times 1.50 \mathrm{~m} \times 0.20 \mathrm{~m}$ of the State Key Laboratory of Coal Resources and Safe Mining of China University of Mining and Technology is used. The upper part of the test bench is equipped with cylinder loading system, and the model can be loaded by air pump. The image acquisition uses the digital photogrammetry system [24] independently developed by China University of Mining and Technology to track and shoot the whole process with fixed camera position and accurately calculate the movement of each point of the rock stratum through the image processing software in the later stage. During the model laying process, the Earth pressure cells are embedded, and the digital high-speed strain gauge is connected to monitor the rock stress of each layer during the experiment. The support model is pressurized by a manual hydraulic oil pump to adjust the height and support force of the support. 
In the similar model, the following similar materials of rock stratum were selected: aggregate: ordinary fine-grained river sand after screening (particle size is less than $3 \mathrm{~mm}$ ); cementitious material: gypsum, cement, calcium carbonate; layered material: mica powder. Before making the model, the aggregate and cement were weighed according to different proportions, mixed and stirred evenly with water, and the similar material experiment pieces were made, and their mechanical properties were measured after drying. After repeated tests, the final proportion of model materials was determined to meet the requirements of mechanical similarity.

High-density foam, low-density foam, and sponge material were selected for different height combinations to form 6 kinds of similar materials of filling body, as shown in Table 1. These six materials were tested for the characteristics of compaction strength. At the same time, according to the compaction test curve of the original slag mixture filling body [25], the theoretical value of stress and strain of the model material of the filling body used in the similar model was calculated according to the mechanical similarity ratio. The theoretical values were compared with the compaction curves of six model materials of the filling body, as shown in Figure 4. Among them, the stress-strain curve of No. 6 material was the closest to the theoretical curve, so this paper finally determined that No. 6 model material was selected as the model material of the filling body.

\subsection{Experiment Scheme and Process of Similar Material} Models. The aforementioned coal mine is in Shanxi Province, China. The coal seams mined in the working face are located in the strata of the Shanxi formation of the Permian system, which are continental lacustrine deposits. The structure of the coal seams is simple, the thickness of the coal seams is stable and minable, the average thickness of the coal seams is $3 \mathrm{~m}$, and the average dip angle of the coal seams is $7^{\circ}$. It can be approximately considered as a horizontal coal seam. The direct roof of $2 \#$ coal seam is composed of sandy mudstone and fine sandstone, and the direct floor of 2\# coal seam is composed of mudstone. The coal seam is $125 \mathrm{~m}$ deep, with roads and buildings on the ground. The lithological characteristics of the strata above and below the coal seam are shown in Table 2.

In order to study the interaction relationship among support, roof rock, and filling body under the condition of filling and fully mechanized mining, two parallel similar models were laid. Under the condition that the mining height is fixed and the initial filling height is different, the movement law of the strata is simulated. When the model was mined, both sides of the seam were cut, and no boundary was left, which is used to simulate the deformation law from the comprehensive mechanized solid filling mining face to the direction of the middle part of the stope.

The geometric similarity ratio of both models was $\alpha_{l}=\left(y_{m} / y_{p}\right)=\left(z_{m} / z_{p}\right)=(1 / 27)$. The mounting height was $1.015 \mathrm{~m}$, and the total thickness of the simulated rock stratum was $27.41 \mathrm{~m}$, of which the thickness of the coal seam was $3 \mathrm{~m}$. The bulk density similarity coefficient of the model was $\alpha_{\gamma 0}=\left(\gamma_{m i} / \gamma_{p i}\right)=0.60$. According to the similarity simulation theory, the elastic modulus similarity coefficient is the product of the geometric similarity ratio and the bulk density similarity ratio. After calculation, its value was $\alpha_{E}=(1 / 44)$, the upper loading was $0.06 \mathrm{MPa}$ to simulate the gravity of the $105 \mathrm{~m}$ overburden. The mixture ratios of similar materials of rock stratum are shown in Table 3.

In the actual filling and mining process, the filling body is pushed after being filled into the mined-out area to make it connect to the top. Therefore, in the experiment, the combined height of foam and sponge was made to reach the mining height first, and the process of compressing the sponge was used to simulate the initial pushing process. Since the initial filling heights of the two models were different, when the combined height of the foam and sponge reached the initial filling height under the action of the compressive force of $10 \mathrm{kPa}$, the height of each material was finally determined according to the principle of the height ratio of the No.6 model material. Similar model experiment scheme and the combination design of foam and sponge of backfilling materials are shown in Table 4.

After the model was laid, the corresponding displacement measuring points were arranged, and three rows of displacement measuring lines were arranged from bottom to top, with the vertical heights of $0.27 \mathrm{~m}, 0.36 \mathrm{~m}$, and $0.80 \mathrm{~m}$, respectively. Each row of displacement measuring lines was arranged with 19 measuring points from right to left, with a spacing of $12.5 \mathrm{~cm}$. Each row of displacement measuring lines was arranged with 19 measuring points, measuring point (1) was located at a position $12.5 \mathrm{~cm}$ from the right edge, and then measuring point (2) measuring point (19) were arranged in sequence from right to left, with the distance $12.5 \mathrm{~cm}$ between each other. After conversion according to the similarity ratio, in the actual rock stratum, the corresponding position of measuring point (1) was the position where the mining length was $3.375 \mathrm{~m}$ from the right boundary, and the corresponding position of measuring point 2 was the position where the mining length was $6.75 \mathrm{~m}$. By analogy, the actual distance between each two measuring points was $3.375 \mathrm{~m}$.

During the experiment, all kinds of materials and equipment required were prepared first, the river sand, gypsum, calcium carbonate and cement, and other materials were screened and fully air-dried, then laid the model. After air-drying, corresponding displacement measuring points were arranged, the digital high-speed strain gauge was connected, and the cylinder was then loaded from the top of the model until the model was fully stable. The boundary effect was considered in the similar material model experiment. In order to reduce the influence of the boundary effect, both sides of the model were cut. The specific experiment steps were as follows: (1) Excavated from right to left without leaving a boundary on the right. Excavated $25 \mathrm{~cm}$ for the first time, put in the support model, and set the initial support force and height of the support according to each scheme. After the model was fully stabilized, data were recorded, photos were taken, and the photo number was recorded. (2) Excavated $5 \mathrm{~cm}$, data were recorded, photos were taken, and the photo number was recorded. (3) Moved 
TABLe 1: Combination design of wood and sponge for different filling ratios.

\begin{tabular}{ccccc}
\hline No. & $\begin{array}{c}\text { Height of high-density } \\
\text { foam }(\mathrm{cm})\end{array}$ & $\begin{array}{c}\text { Height of low-density } \\
\text { foam }(\mathrm{cm})\end{array}$ & $\begin{array}{c}\text { Height of } \\
\text { sponge }(\mathrm{cm})\end{array}$ & $\begin{array}{c}\text { Height ratio } \\
\text { (high-density foam:low-density foam:sponge) }\end{array}$ \\
\hline 1 & 7.5 & 0 & 3 & $5:--: 2$ \\
2 & 10 & 0 & 1 & $10:--: 1$ \\
3 & 6.6 & 2.4 & 2 & $33: 12: 10$ \\
4 & 8 & 0 & 2 & $8:--: 2$ \\
5 & 4.25 & 5 & 2 & $17: 20: 8$ \\
6 & 9 & 0 & $9:--: 2$ \\
\hline
\end{tabular}

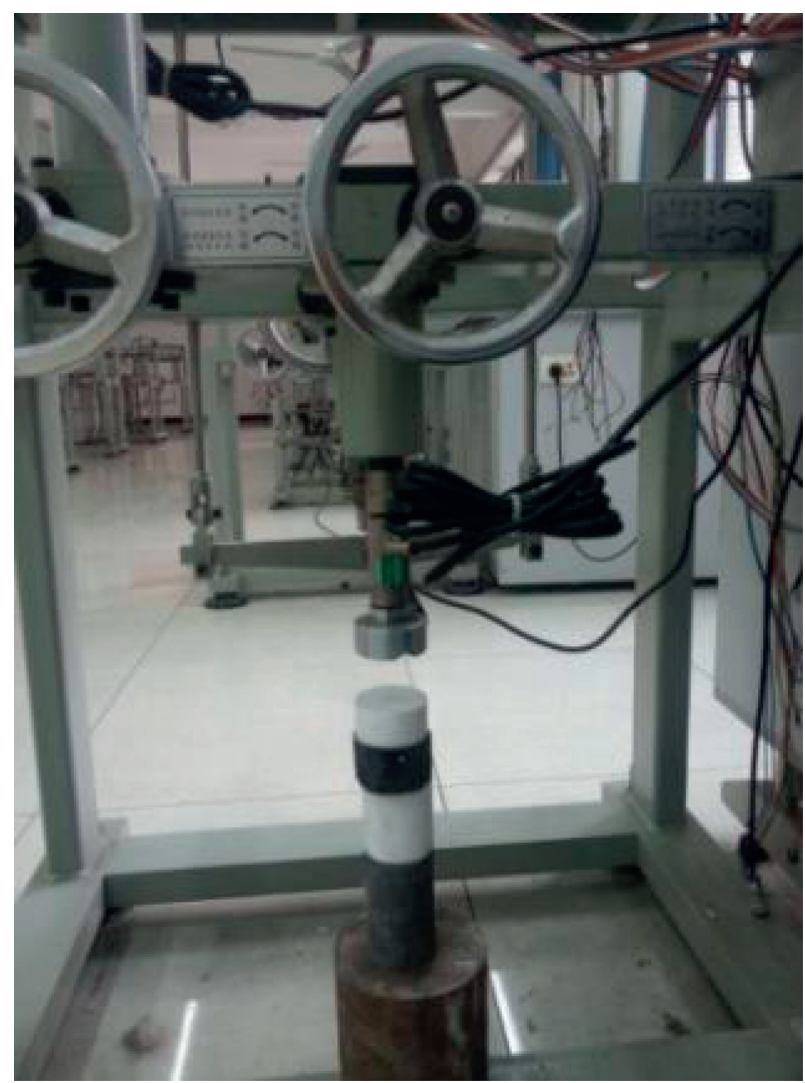

(a)

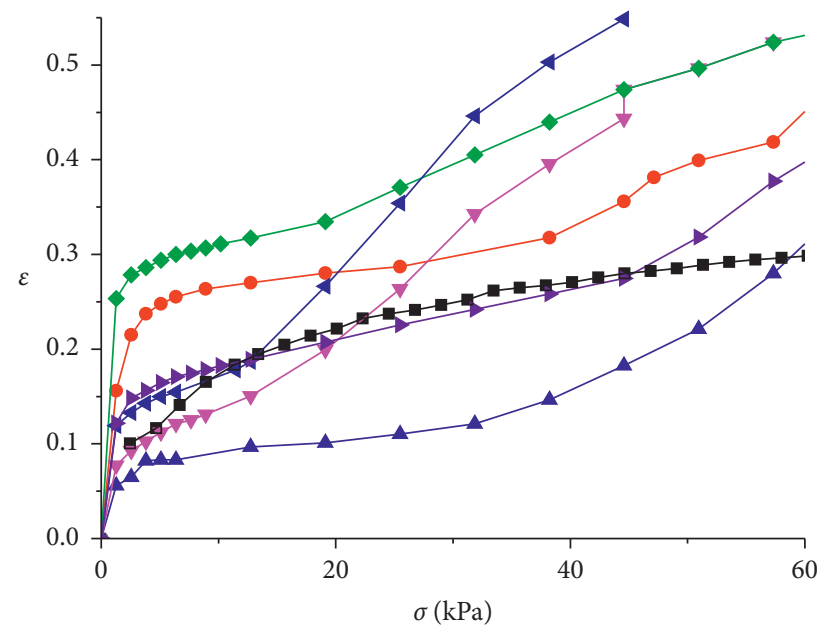

$\rightarrow$ Theoretical value of similar malerial

$\rightarrow$ No.1 model material

—- No.2 model material

$\neg$ No.3 model material

$\multimap-$ No.4 model material

$\dashv$ No.5 model material

$\rightarrow$ No.6 model material

Figure 4: Compaction test photos and curves of similar materials of filling body. (a) Compaction test photos. (b) Compaction test curves.

the support $5 \mathrm{~cm}$ forward and fill it at the rear. After the model was fully stabilized, data were recorded, photos were taken, and the photo number was recorded. (4) Repeated steps (2) to (3) until the model was fully mined and filled.

3.3. Influence of Initial Filling Height on Deformation of Roof Rock and Backfilling Body. The initial filling heights of Model I and Model II were $6.67 \mathrm{~cm}$ and $10.56 \mathrm{~cm}$, respectively, which were $60 \%$ and $95 \%$ of the mining height. The deformation law of surrounding rock and filling body and the change law of pressure cell data during the filling mining process were recorded. The actual photos of the mining length of $20 \mathrm{~m}, 32 \mathrm{~m}$, and $49 \mathrm{~m}$ are shown in Figure 5. The displacement of roof strata was tracked and analyzed by using image processing software Photoinfor. The displacement was calculated according to the pixel coordinates of the image, and the displacement nephogram and vector diagram were obtained, as shown in Figures 6 and 7. The displacement of every measuring point of line 1 above the coal seam in the process of filling mining was extracted, and the result is shown in Figure 8.

It can be seen from Figures 5-8 that when the initial filling height is $60 \%$ of the mining height (model I), the movement of rock strata is very obvious. When the mining length is $8 \mathrm{~m}$ (Figure 6(a)), the roof above the goaf begins to sink, and the maximum subsidence of the rock strata above the broken direct roof is $0.01 \mathrm{~m}$. When the mining length was $20 \mathrm{~m}$, the roof above the goaf began to sink more obviously, the maximum subsidence was $0.30 \mathrm{~m}$, and discontinuous cracks began to appear in the roof strata (as shown by the red dotted line in Figure 5(a)), and the first relatively complete rotary area appeared (as shown in the red quadrilateral in Figure 6(b)); the displacement of measuring 
TABLE 2: The lithological characteristics of the strata.

\begin{tabular}{|c|c|c|c|c|}
\hline Stratum position & Rock name & Lithology description & Depth $(\mathrm{m})$ & Thickness $(\mathrm{m})$ \\
\hline \multirow{8}{*}{ Overlying strata } & Siltstone & $\begin{array}{c}\text { Dark grey; broken locally; uneven cross section and } \\
\text { inclined fracture. }\end{array}$ & 105.30 & 1.17 \\
\hline & Sandy mudstone & $\begin{array}{c}\text { Dark grey; flat section, small wavy bedding, and } \\
\text { inclined fracture. }\end{array}$ & 110.95 & 5.65 \\
\hline & Siltstone & $\begin{array}{l}\text { Dark grey; highly-weathered and } \\
\text { broken locally; flat section. }\end{array}$ & 114.90 & 3.95 \\
\hline & Sandy mudstone & Dark grey; wavy bedding; vertical fracture. & 117.10 & 2.20 \\
\hline & Fine-grained sandstone & $\begin{array}{c}\text { Light grey; broken locally; sub angular in shape and } \\
\text { medium in sorting. }\end{array}$ & 119.05 & 1.95 \\
\hline & Mudstone & $\begin{array}{c}\text { Dark grey; highly-weathered; flat section and } \\
\text { inclined fracture. }\end{array}$ & 120.30 & 1.25 \\
\hline & Fine-grained sandstone & $\begin{array}{l}\text { Light grey; not weathered; medium sorted; } \\
\text { cross bedded, subangular, vertical fracture, and } \\
\text { occasionally inclined fracture. }\end{array}$ & 122.65 & 2.35 \\
\hline & Sandy mudstone & Dark grey; flat section; strongly weathered. & 123.15 & 0.50 \\
\hline \multirow{3}{*}{ Coal seam } & Coal & Black, massive and fragmentary; glass luster. & 124.80 & 1.65 \\
\hline & Mudstone & $\begin{array}{l}\text { Dark grey; highly-weathered; flat section; } \\
\text { wavy bedding; inclined fracture. }\end{array}$ & 125.05 & 0.25 \\
\hline & Coal & Black, massive and fragmentary; glass luster. & 125.66 & 0.61 \\
\hline Floor stratum & Mudstone & $\begin{array}{l}\text { Grey; highly-weathered; wavy bedding; flat section and } \\
\text { inclined fracture. }\end{array}$ & 131.05 & 5.39 \\
\hline
\end{tabular}

TABLE 3: Layer programs and mixture ratios of similar model.

\begin{tabular}{|c|c|c|c|c|c|c|c|c|}
\hline Rock layer name & $\begin{array}{c}\text { Model } \\
\text { thickness }(\mathrm{m})\end{array}$ & $\begin{array}{c}\text { Layer } \\
\text { number }\end{array}$ & $\begin{array}{l}\text { Mass per } \\
\text { layer (kg) }\end{array}$ & $\begin{array}{l}\text { Sand } \\
(\mathrm{kg})\end{array}$ & $\begin{array}{l}\text { Cement } \\
(\mathrm{kg})\end{array}$ & $\begin{array}{c}\text { Calcium } \\
\text { carbonate } \\
(\mathrm{kg})\end{array}$ & $\begin{array}{c}\text { Gypsum } \\
\text { (kg) }\end{array}$ & $\begin{array}{c}\text { Water } \\
(\mathrm{kg})\end{array}$ \\
\hline Siltstone & 0.043 & 2 & 17.333 & 13.000 & 0.000 & 2.167 & 2.167 & 1.733 \\
\hline Sandy mudstone & 0.209 & 6 & 27.901 & 20.926 & 0.000 & 3.488 & 3.488 & 2.790 \\
\hline Siltstone & 0.146 & 4 & 29.259 & 23.407 & 0.000 & 1.756 & 4.096 & 2.926 \\
\hline Sandy mudstone & 0.081 & 2 & 32.593 & 24.444 & 0.000 & 4.074 & 4.074 & 3.259 \\
\hline $\begin{array}{l}\text { Fine-grained } \\
\text { sandstone }\end{array}$ & 0.072 & 2 & 28.889 & 26.000 & 2.022 & 0.000 & 0.867 & 2.889 \\
\hline Mudstone & 0.046 & 2 & 18.519 & 15.873 & 0.000 & 0.794 & 2.646 & 1.852 \\
\hline $\begin{array}{l}\text { Fine-grained } \\
\text { sandstone }\end{array}$ & 0.087 & 3 & 23.210 & 17.407 & 0.000 & 1.741 & 4.062 & 2.321 \\
\hline Sandy mudstone & 0.019 & 1 & 14.815 & 11.111 & 0.000 & 1.852 & 1.852 & 1.481 \\
\hline Coal & 0.111 & 3 & 29.630 & 25.926 & 0.000 & 2.593 & 1.111 & 2.963 \\
\hline Mudstone & 0.120 & 5 & 31.941 & 23.956 & 0.000 & 2.396 & 5.590 & 3.194 \\
\hline
\end{tabular}

TABLE 4: Similar model experiment scheme and combination design of foam and sponge for two models.

\begin{tabular}{lccccc}
\hline & $\begin{array}{c}\text { Actual mining } \\
\text { height }(\mathrm{m})\end{array}$ & $\begin{array}{c}\text { Actual initial filling } \\
\text { height }(\mathrm{m})\end{array}$ & $\begin{array}{c}\text { Height of high density } \\
\text { foam }(\mathrm{cm})\end{array}$ & $\begin{array}{c}\text { Height of sponge } \\
(\mathrm{cm})\end{array}$ & $\begin{array}{c}\text { Combined height after initial } \\
\text { compression }(\mathrm{cm})\end{array}$ \\
\hline ModelI & 3.0 & 1.8 & 5.45 & 5.65 & 6.67 \\
ModelII & 3.0 & 2.85 & 8.64 & 2.46 & 10.56 \\
\hline
\end{tabular}

points (1) and (2) of line 1 above the coal seam also began to increase significantly (Figure $8(\mathrm{a})$ ). When the mining length was $32 \mathrm{~m}$, the first rotary area continued to sink and gradually turned to the horizontal direction (Figure 6(c)), small cracks began to appear in front of it (as shown by the red dotted line in Figure 5(b)), and a second rotary area appeared (as shown in the red quadrilateral in Figure 6(c)); the displacement of measuring points (1), (2), and (3) of measuring line 1 above the coal seam increased stepwise (Figure 8(a)), and the maximum subsidence was $0.87 \mathrm{~m}$.

When the mining length was $40 \mathrm{~m}$, the second rotary area basically formed and turned (Figure 6(d)), and there were many cracks on the roof. The speed of displacement increase of measuring points (1), (2), and (3) of line 1 above the coal seam slowed down. The displacement of measuring points (4) and (5) increased at a larger speed (Figure 8(a)), and the maximum subsidence was $1.14 \mathrm{~m}$. When the mining length was $49 \mathrm{~m}$, the cracks on the roof above the first rotary area gradually closed, the roof above the working face started to produce small cracks (as shown by the red dotted line in Figure 5(c)), and the third rotary area appeared (as shown in the red quadrilateral in Figure 6(e)). The displacement of measuring points (1), (2), and (3) tended to be stable, and the increase speed of displacement of measuring point (4) slowed 


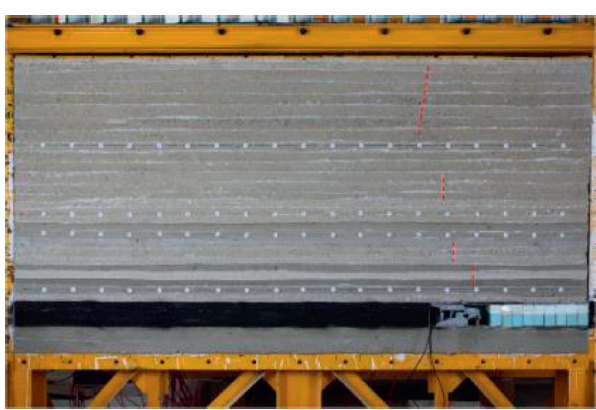

(a)

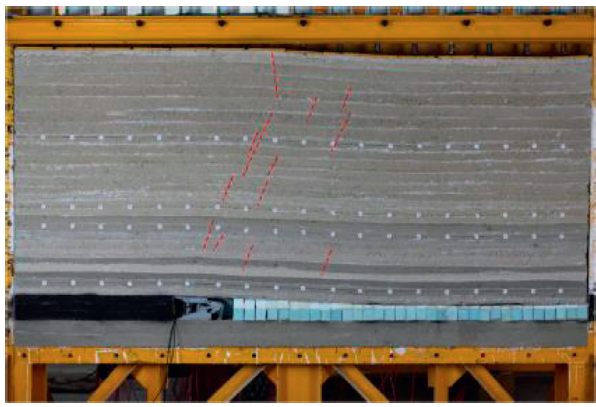

(c)

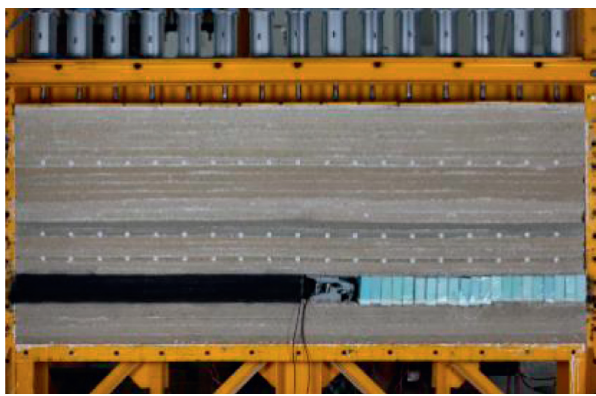

(e)

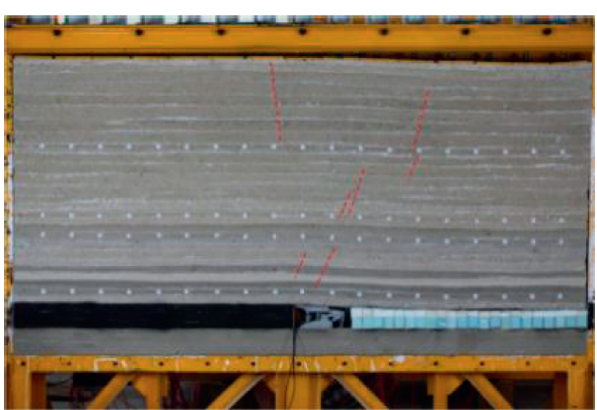

(b)

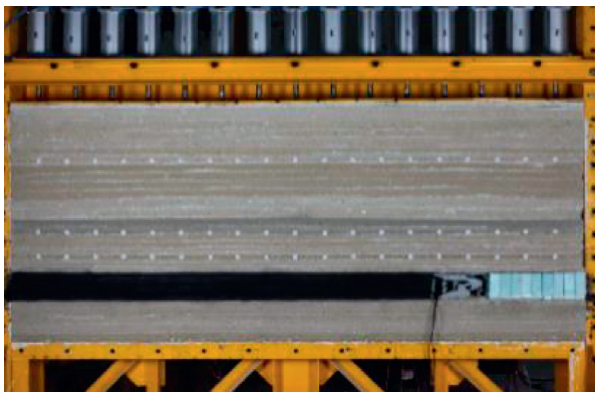

(d)

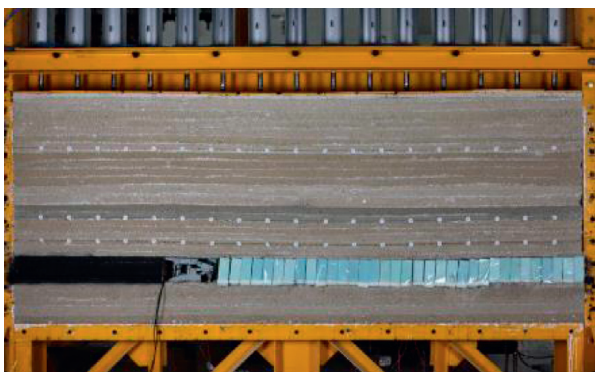

(f)

Figure 5: The process of mining and filling and the change of rock strata displacement. (a) Model I, mining length $20 \mathrm{~m}$. (b) Model I, mining length $32 \mathrm{~m}$. (c) Model I, mining length $49 \mathrm{~m}$. (d) Model II, mining length $20 \mathrm{~m}$. (e) Model II, mining length $32 \mathrm{~m}$. (f) Model II, mining length $49 \mathrm{~m}$.

down, with the maximum subsidence of $1.21 \mathrm{~m}$. When the mining length was $57 \mathrm{~m}$ (Figure 6(f)), the third rotary area was basically formed, and there were more cracks in the roof. At the same time, the first two areas continued to sink, and the second area turned to the horizontal direction gradually; the displacement of measuring point (4) tended to be stable, and the increase speed of displacement of measuring point (5) slowed down, the maximum subsidence was $1.27 \mathrm{~m}$. When the mining length was $65 \mathrm{~m}$ (Figure $6(\mathrm{~g})$ ), the third area rotated, the cracks in the first two areas were basically closed, the displacement of measuring points (6) to (8) continued to increased rapidly, and the maximum subsidence was $1.36 \mathrm{~m}$.

On the whole, when the initial filling height is $60 \%$ of the mining height, the roof sinks obviously. During the mining process, the movement of the roof is similar to the traditional caving method, the periodic fracture occurs, and the masonry beam structure is formed. However, the comprehensive mechanized filling and mining method of mining and filling at the same time well limits the scope and speed of roof collapse, so that the roof can basically maintain integrity. The filling body is gradually compacted during the advancing period of the mining face, and each rotary area of the roof gradually contacts the filling body in the process of rotation, and the filling body is initially compacted. After the completion of rotation, in the stage of horizontal subsidence, the filling body is fully compacted; only at this time, the filling body can play the role of supporting the roof and controlling the roof subsidence. It can also be seen from the change of the measuring point displacement that after the mining face pushes over the measuring point, the roof strata sink rapidly at first, after $20 \sim 30 \mathrm{~m}$ of filling, then gradually sink slowly until they are stable. The final stable subsidence of the roof is $1.36 \mathrm{~m}$ in the experiment, which is in good agreement with the theoretical calculation value of $1.38 \mathrm{~m}$ when $h_{\mathrm{g}}=1.8 \mathrm{~m}$ (60\% of the mining height) in Section 2.2.

It can be seen from Figures 5-8 that when the initial filling height is $95 \%$ of the mining height (model II), the overall subsidence of the rock stratum is relatively small. 

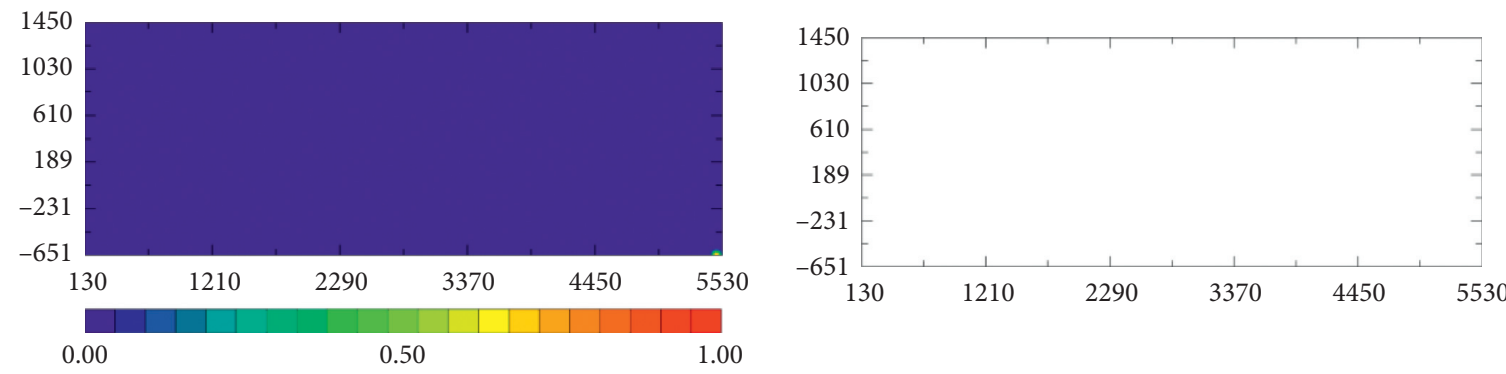

(a)
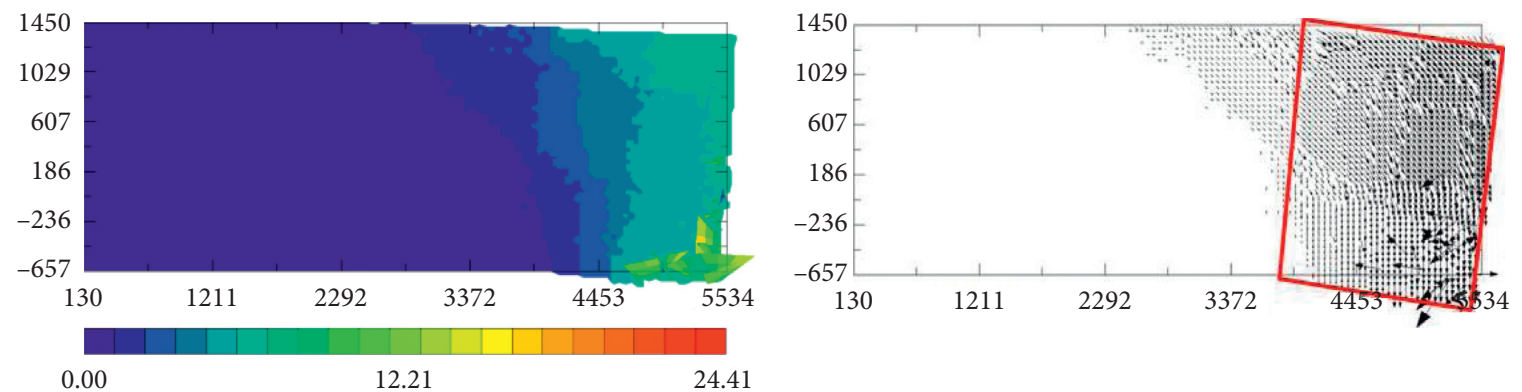

(b)
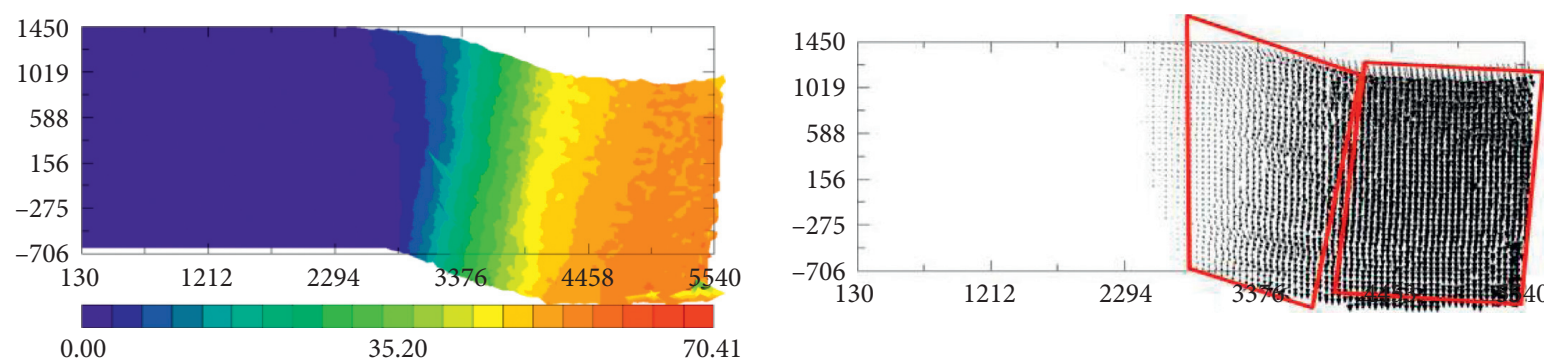

(c)
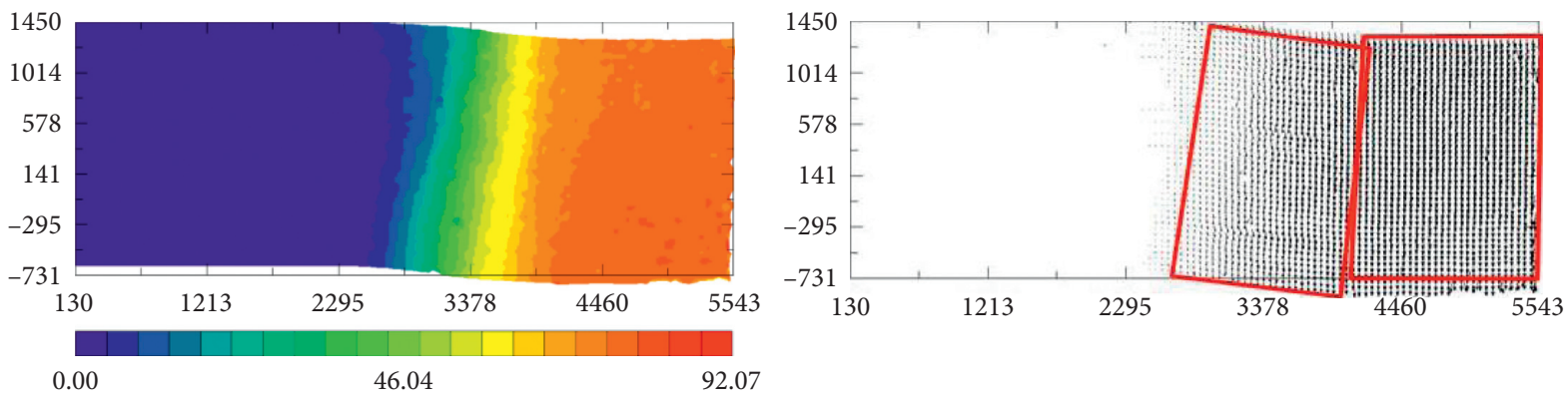

(d)
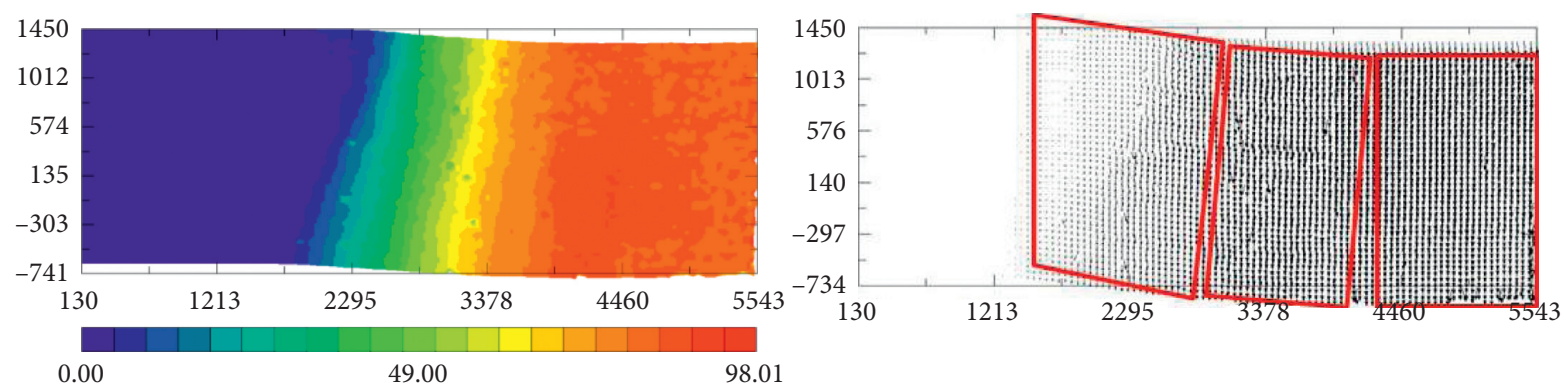

(e)

Figure 6: Continued. 

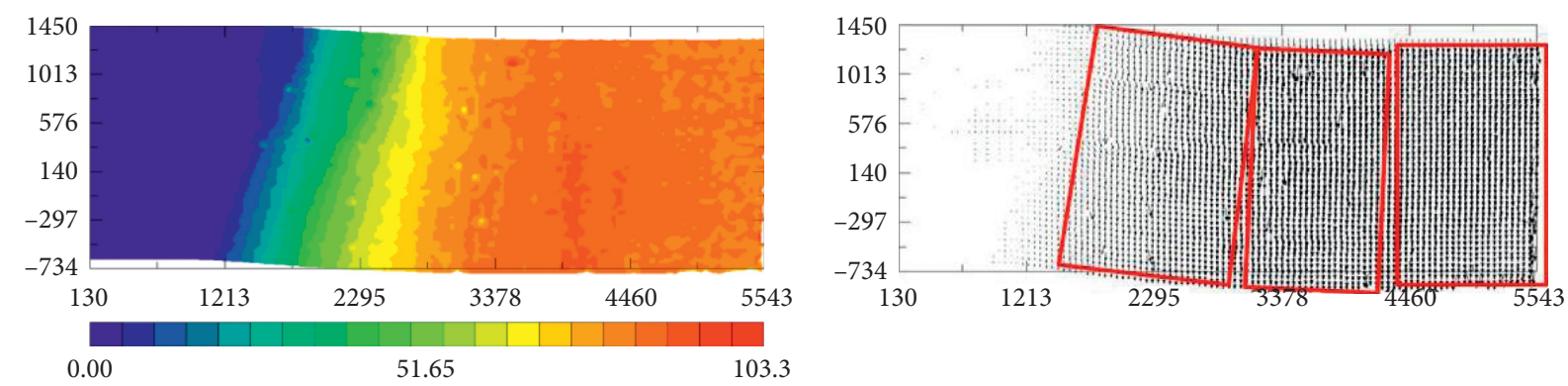

(f)
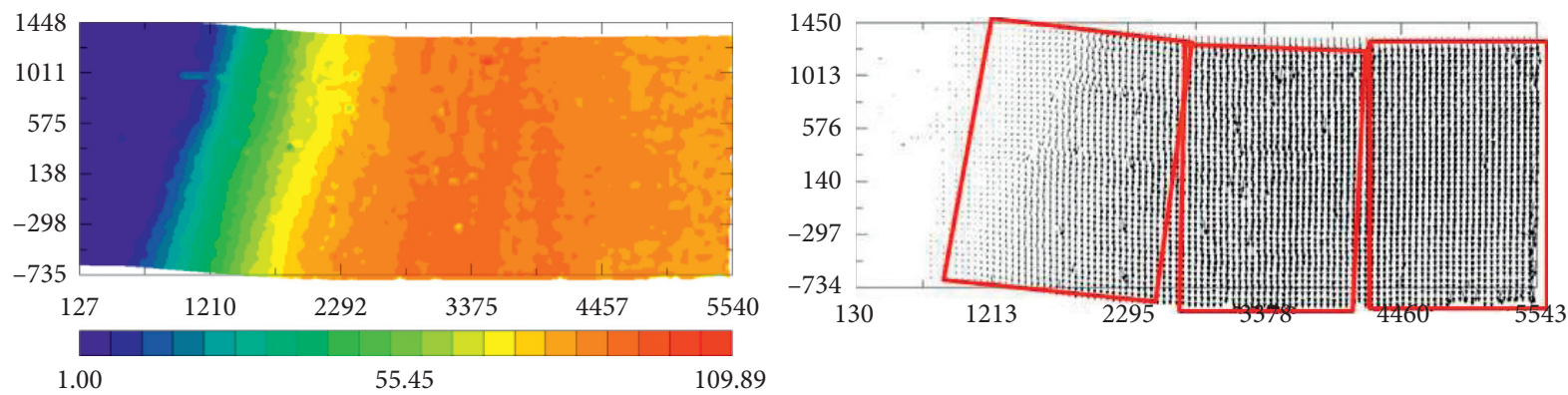

(g)

FIGURE 6: Displacement nephograms and vector diagrams of rock strata in the process of mining and filling of model I: (a) mining length $8 \mathrm{~m}$, (b) mining length $20 \mathrm{~m}$, (c) mining length $32 \mathrm{~m}$, (d) mining length $40 \mathrm{~m}$, (e) mining length $49 \mathrm{~m}$, (f) mining length $57 \mathrm{~m}$, and (g) mining length $65 \mathrm{~m}$.

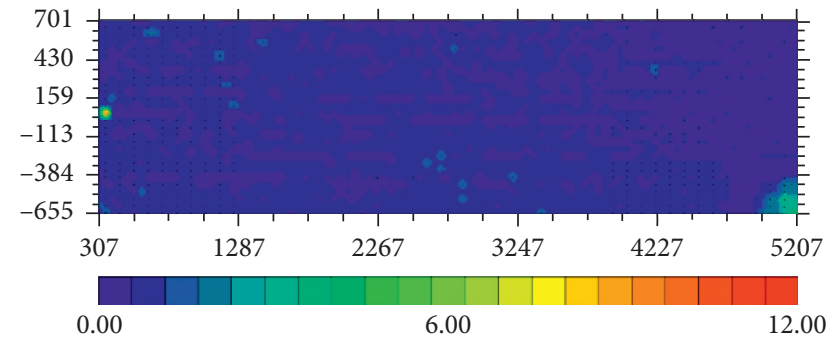

(a)

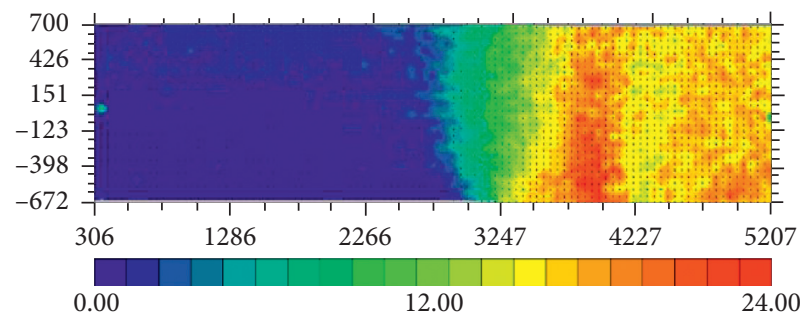

(c)

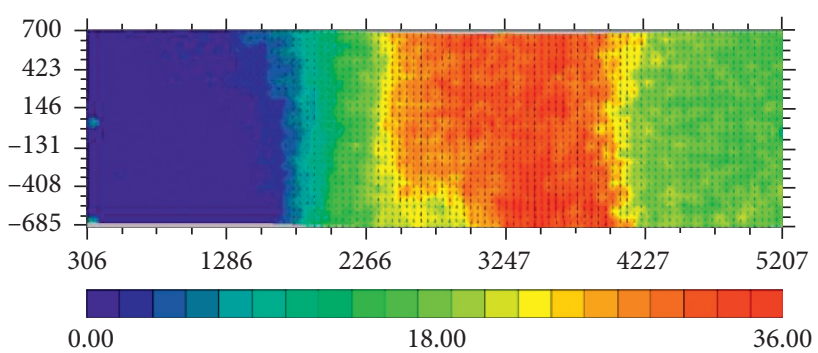

(e)

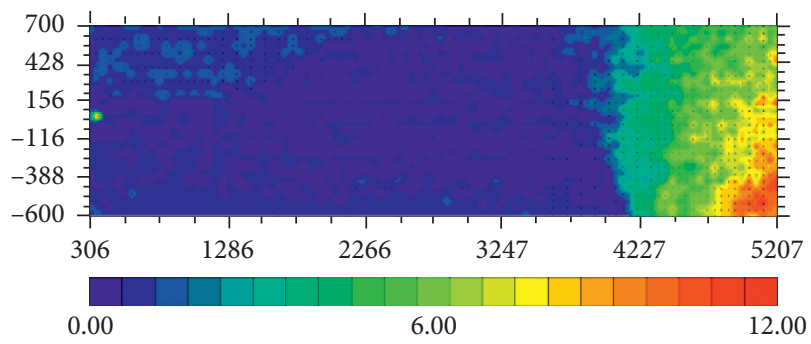

(b)

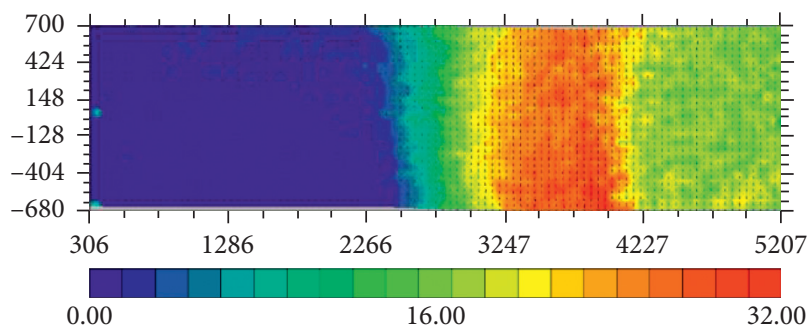

(d)

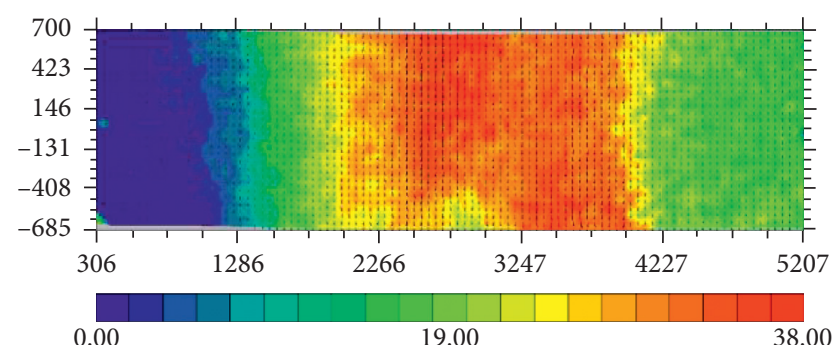

(f)

Figure 7: Continued. 


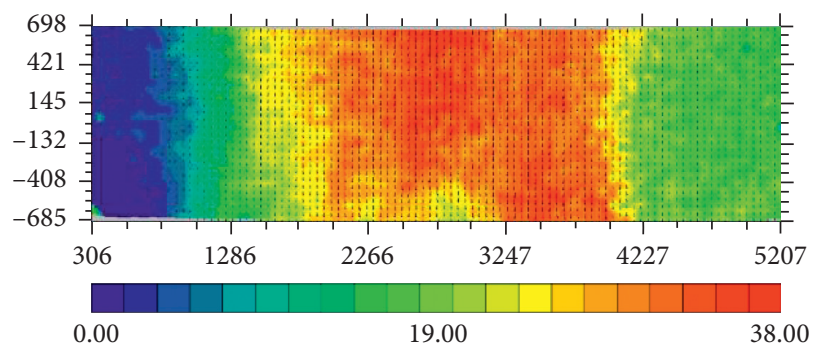

(g)

FIGURE 7: The process of mining and filling and the change of rock strata displacement in model II: (a) mining length $8 \mathrm{~m}$, (b) mining length $20 \mathrm{~m}$, (c) mining length $32 \mathrm{~m}$, (d) mining length $40 \mathrm{~m}$, (e) mining length $49 \mathrm{~m}$, (f) mining length $57 \mathrm{~m}$, and (g) mining length $65 \mathrm{~m}$.

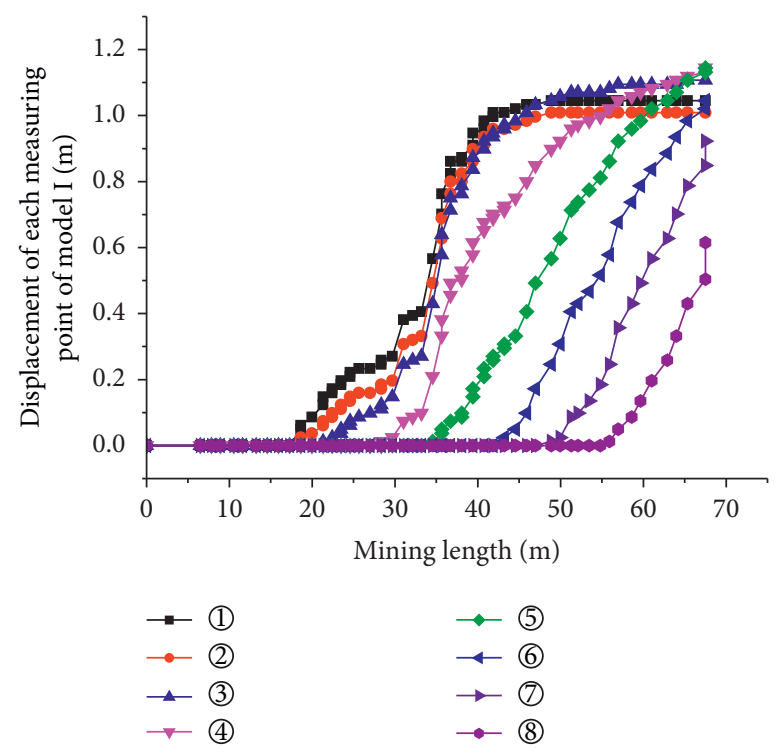

(a)

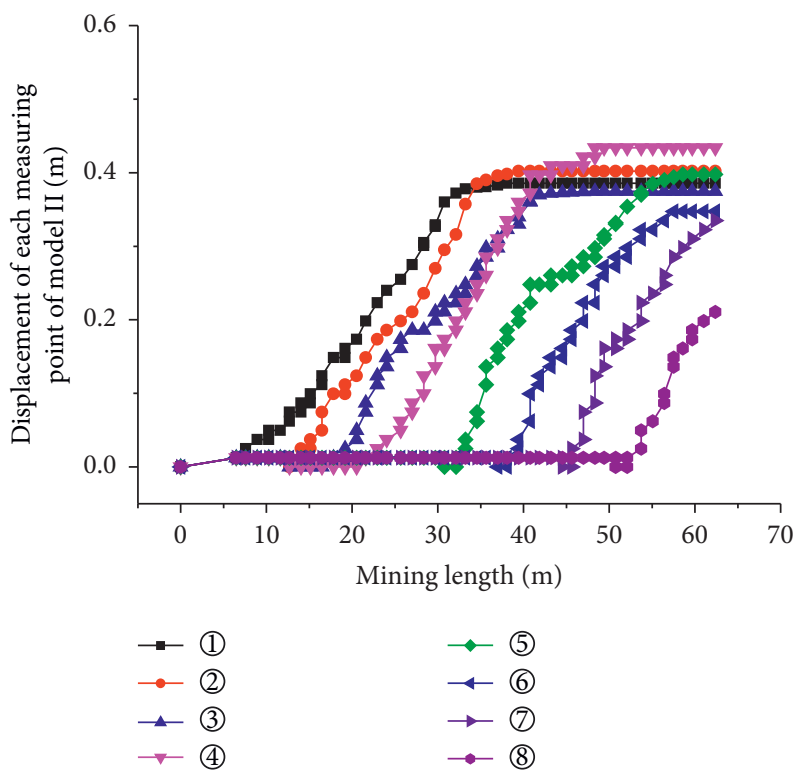

(b)

FIGURE 8: The displacements of the measuring points in the line 1 in the process of mining and filling: (a) model I and (b) model II.

During the entire mining and filling process, no obvious bending of the roof strata was observed, only small subsidence occurred (Figures 5(d)-5(f)). When the mining length is $20 \mathrm{~m}$ (Figure $7(\mathrm{~b})$ ), the maximum subsidence is only $0.14 \mathrm{~m}$; when the mining length is $40 \mathrm{~m}$ (Figure $7(\mathrm{~d})$ ), the maximum subsidence is only $0.39 \mathrm{~m}$; when the mining length is $65 \mathrm{~m}$ (Figure $7(\mathrm{~g})$ ), the maximum subsidence is only $0.47 \mathrm{~m}$, which is in good agreement with the theoretical calculation value of $0.44 \mathrm{~m}$ when $h_{\mathrm{g}}=2.85 \mathrm{~m}$ (95\% of the mining height) in Section 2.2. The displacement of each measuring point of measuring line 1 above the coal seam does not show an episodic increase, but it continues to increase steadily after the mining face pushes over the measuring point and reaches a stable value after filling about $22 \mathrm{~m}$. This distance is also very close to the theoretical calculation value of filling distance $x=25 \mathrm{~m}$ corresponding to the stable subsidence of the roof in the filling area in Section 2.2. This shows that when the initial filling height is 95\% of the mining height, the filling body can replace the coal seam to support the roof timely and play an important

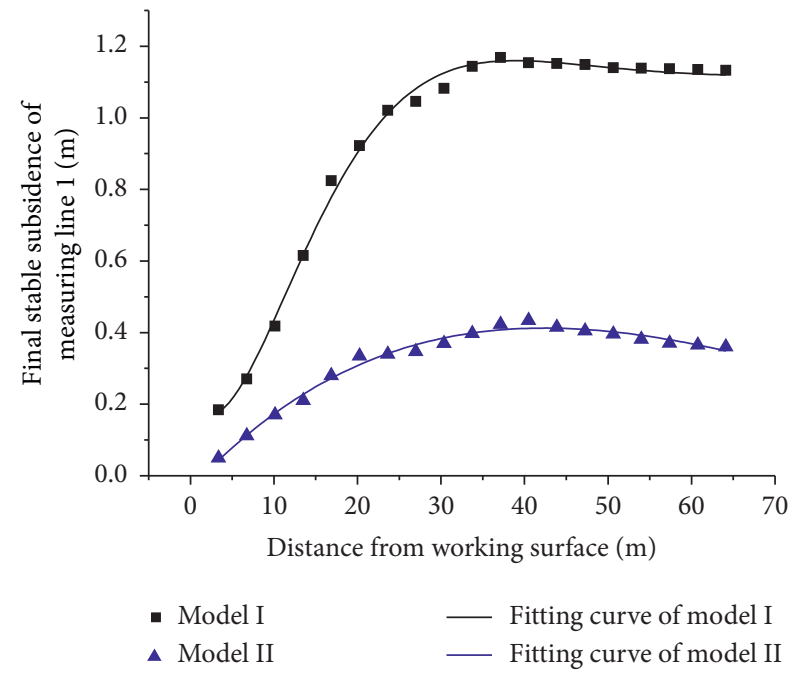

Figure 9: Experiment value and fitting curve of the final stable subsidence of measuring line 1 in two models. 
role in controlling the subsidence and migration of roof rock beams.

In conclusion, the initial filling height has a significant effect on the movement and subsidence of the overlying strata in the process of mining and filling. After the completion of the process of mining and filling, the final subsidence displacement of each measuring point on measuring line 1 of the two models is recorded and compared, as shown in Figure 9. It can be seen that with the increase of the distance away from the mining face, that is, the increase of the filling length, the final subsidence of each model roof presents the trend of rapid increase at first and then gradually stabilizes. The final stable subsidence of model I is about $1.1 \mathrm{~m}$, which is only about $0.4 \mathrm{~m}$ in model II. The filling distance corresponding to the stable subsidence of the roof also decreases with the increase of the initial filling height. In model I, after $35 \mathrm{~m}$ of filling, the roof subsidence gradually stabilized; in model II, after $22 \mathrm{~m}$ of filling, the roof subsidence becomes stable.

The final subsidence curves of roof measuring line 1 of model I and model II are function-fitted, as shown in Figure 9. The fitting function is

$$
\begin{aligned}
& \text { model I : } y=e^{-0.086 x}[-1.340 \sin (0.086 x)-0.912 \cos (0.086 x)]+1.119, \\
& \text { model II : } y=e^{-0.015 x}[2.021 \sin (0.015 x)+0.326 \cos (0.015 x)]-0.362
\end{aligned}
$$

The form of fitting function is the same as that of theoretical formula (9). The correlation coefficients of fitting are 0.996 and 0.985 , respectively, which has a good fitting result. This shows that the similar simulation experiment results are consistent with the theoretical calculation values of roof subsidence law.

\section{Conclusion}

Based on the theory of elastic foundation beam, the mechanical model of the backfilling mining support-roof rock beam-gangue filling body is established. Under the condition of comprehensive mechanized filling mining, the subsidence differential equation of roof rock beam is solved, and the foundation coefficient in the model is discussed in combination with the compaction mechanical property of gangue filling body. The subsidence displacements of roof at the coal wall, above the support and above the filling body are obtained. On the basis of similarity theory and mechanical test of similar materials of gangue filling body, simulation experiments of filling mining were carried out. From the theoretical analysis and experimental observation, the influence of initial filling height and compaction force of filling support on the subsidence of roof rock beam is discussed respectively. Some conclusions can be drawn as follows:

(1) The initial filling height is the decisive factor to control the subsidence and migration stability of each part of the roof rock beam. The larger the initial filling height is, the smaller the final subsidence of each part of the roof rock beam is, and the shorter the corresponding filling length is when the roof rock beam above the filling area reaches the final stable subsidence.

(2) The compaction force of the backfilling mining support on the gangue filling body has a certain influence on the subsidence of roof rock beam, which is mainly reflected in the filling area. Appropriately increasing the compaction force of the support can compact the backfilling body effectively and increase its deformation modulus, thus controlling the subsidence and unstable range of the roof rock beam. When the compaction stress is about 2.0 MPa, the subsidence of roof rock beam can be effectively controlled. If the compaction stress is increased, this control effect will not increase significantly.

(3) In view of the two cases where the initial filling height is $60 \%$ and $95 \%$ of the mining height, respectively, two similar simulation experiment models are set up to carry out the simulation experiment research on the filling mining process. The experiment results show that the maximum subsidence of the roof rock beam and the corresponding filling length when the roof rock beam reaches the final stable subsidence are consistent with the theoretical calculation value. The experiment curve fitting function of the final subsidence is consistent with the expression form of the theoretical calculation result. In addition, similar simulation experiment can better reflect the movement characteristics of roof strata during the entire filling mining process.

The mechanical model and research results presented in this paper shed light on better understanding of the interaction among support, roof rock beam, and backfilling body in the process of comprehensive mechanized backfilling mining.

\section{Data Availability}

The data used to support the findings of this study are available from the corresponding author upon request.

\section{Conflicts of Interest}

The authors declare no conflicts of interest. 


\section{Acknowledgments}

This work was supported by National Natural Science Foundation of China, grant nos. 51804302 and 51674250, China Postdoctoral Science Foundation, grant no. 2019M652018, Major Program of National Natural Science Foundation of China, grant nos. 51734009 and 51323004, and National Key Research and Development Projects of China, grant no. 2019YFC1904304. The authors sincerely acknowledge the former researchers for their excellent work, which greatly assisted our academic study.

\section{References}

[1] M.-G. Qian, J.-1. Xu, and X.-X. Miao, "Green technique in coal mining," Journal of China University of Mining \&. Technology, vol. 32, no. 4, pp. 343-348, 2003.

[2] M.-G. Qian, X.-X. Miao, J.-l. Xu et al., "On scientized mining," Journal of Mining \& Safety Engineering, vol. 25, no. 1, pp. 1-10, 2008.

[3] M.-G. Qian, X.-X. Miao, and J.-1. Xu, "Resources and environment harmonics (green) mining and its technological system," Journal of Mining \& Safety Engineering, vol. 23, no. 1, pp. 1-5, 2006.

[4] M.-G. Qian and J.-1. Xu, "Concept and technical framework of sustainable mining," Journal of China University of Mining \&. Technology (Social Sciences), vol. 13, no. 3, pp. 1-7, 2011.

[5] J.-X. Zhang, Q. Zhang, A. J. S. Spearing, M. Xiexing, G. Shuai, and S. Qianga, "Green coal mining technique integrating mining-dressing-gas draining-backfilling-mining," International Journal of Mining Science and Technology, vol. 27, no. 1, pp. 17-27, 2017.

[6] X.-X. Miao and J.-X. Zhang, "Key technologies of integration of coal mining gangue washing-backfilling and coal mining," Journal of China Coal Society, vol. 39, no. 8, pp. 1424-1433, 2014.

[7] F. Ju, J.-X. Zhang, Y.-L. Huang et al., "Waste filling technology under condition of complicated geological condition working face," Procedia Earth \& Planetary Science, vol. 1, no. 1, pp. 1220-1227, 2009.

[8] X.-x. Miao, J.-X. Zhang, and M.-M. Feng, "Waste-filling in fully-mechanized coal mining and its application," Journal of China University of Mining and Technology, vol. 18, no. 4, pp. 479-482, 2008.

[9] Y.-J. Zhou, "Study on suitability evaluation of full-mechanized solid back-filling mining technology for difficult-tomine resource," Doctoral dissertation, China University of Mining \& Technology, Xuzhou, China, 2012.

[10] L. Wang, "Study and application on coordination degree of scientific coal mining system," Doctoral dissertation, China University of Mining \& Technology (Beijing), Beijing, China, 2015.

[11] Y.-L. Huang, J.-X. Zhang, B.-F. An, and Q. Zhang, “Overlying strata movement law in fully mechanized coal mining and backfilling longwall face by similar physical simulation," Journal of Mining Science, vol. 47, no. 5, pp. 618-627, 2011.

[12] J.-C. Wang and S.-L. Yang, "Research on support-rock system in solid backfill mining methods," Journal of China Coal Society, vol. 35, no. 11, pp. 1821-1826, 2010.

[13] Z.-G. Ma, J.-Q. Fan, K. Sun, G.-Z. Zhao, and Y.-G. Pan, "Study on stope stability during repeated mining with fully- mechanized solid filling technology in residual coal pillar area,"
Journal of Mining \& Safety Engineering, vol. 28, no. 4, pp. 499-504, 2011.

[14] J. Zhang, Q. Zhang, Y. Huang, J. Liu, N. Zhou, and D. Zan, "Strata movement controlling effect of waste and fly ash backfillings in fully mechanized coal mining with backfilling face," Mining Science and Technology (China), vol. 21, no. 5, pp. 721-726, 2011.

[15] Z.-G. Ma, T. Lan, Y.-G. Pan, J.-G. Ma, and F.-H. Zhu, "Experimental study of variation law of saturated broken mudstone porosity during creep process," Chinese Journal of Rock Mechanics and Engineering, vol. 28, no. 7, pp. 1447-1454, 2009.

[16] Z. Ma, R. Gu, Z. Huang, G. Peng, L. Zhang, and D. Ma, "Experimental study on creep behavior of saturated disaggregated sandstone," International Journal of Rock Mechanics and Mining Sciences, vol. 66, no. 1, pp. 76-83, 2014.

[17] Z. Huang, Z. Ma, L. Zhang, P. Gong, Y. Zhang, and F. Liu, “A numerical study of macro-mesoscopic mechanical properties of gangue backfill under biaxial compression," International Journal of Mining Science and Technology, vol. 26, no. 2, pp. 309-317, 2016.

[18] Z.-M. Huang, Z.-G. Ma, L. Zhang, D.-W. Yang, S.-H. Guo, and D.-P. Liu, "Numerical simulation of the particle flow during the vibration, pushing, and pressing procedure of the backrilling body," Joumnal of Mining \& Safety Engineering, vol. 34, no. 4, pp. 789-794, 2017.

[19] F. Ju, P. Huang, S. Guo, M. Xiao, and L. Lan, "A roof model and its application in solid backfilling mining," International Journal of Mining Science and Technology, vol. 27, no. 1, pp. 139-143, 2017.

[20] X. Du, G. Feng, T. Qi, Y. Guo, Y. Zhang, and Z. Wang, "Failure characteristics of large unconfined cemented gangue backfill structure in partial backfill mining," Construction and Building Materials, vol. 194, pp. 257-265, 2019.

[21] F. Wang, B. Jiang, S. Chen, and M. Ren, "Surface collapse control under thick unconsolidated layers by backfilling strip mining in coal mines," International Journal of Rock Mechanics and Mining Sciences, vol. 113, pp. 268-277, 2019.

[22] Y. Zhang, S. Cao, N. Zhang, and C. Zhao, "The application of short-wall block backfill mining to preserve surface water resources in northwest China," Journal of Cleaner Production, vol. 261, Article ID 121232, 2020.

[23] Z. Liu, "Compaction properties of gangue and it's application in backfilling coal mining," Doctoral dissertation, China University of Mining \& Technology, Xuzhou, China, 2014.

[24] Y.-H. Li and H.-W. Jing, "Software development of a digital speckle correlation method and its application," Journal of China University of Mining \& Technology, vol. 37, no. 5, pp. 635-640, 2008.

[25] Z.-G. Ma, Z.-M. Huang, J.-Q. Fan, G.-Z. Zhao, K. Sun, and F. Liu, "Experimental research on compacting characteristics of open-air slag mixture," China Coal, vol. 38, no. 7, pp. $36-38,2012$. 